\title{
DOES THE ANIMACY OF THE ANTECEDENT PLAY A ROLE IN THE PRODUCTION OF RELATIVE CLAUSES?
}

\author{
Maria Lobo \\ CLUNL / FCSH - Universidade NOVA de Lisboa \\ Stéphanie Vaz \\ CLUNL / FCSH - Universidade NOVA de Lisboa
}

\section{ABSTRACT}

In previous studies that included elicited production and comprehension tasks (Costa, Lobo and Silva 2011), it has been shown that there is a high discrepancy between the rates of production of subject relative clauses vs. object relative clauses both in children and adults, but the two groups differed qualitatively. In the comprehension task, adults performed very well, unlike children, who had trouble with object relative clauses. This points to a specific difficulty with structures that involve intervention (Friedmann, Belletti and Rizzi 2009). In the present study, we investigated the role of animacy features of the antecedent in the production of object relative clauses, and specifically whether the production of object relatives would be higher with inanimate antecedents. Previous studies have mentioned the animacy features of the arguments as relevant (Corrêa 1994; Goodluck 2005; Kidd et al. 2007; Durrleman, Bentea and Guasti 2016). We explore the relevance of the findings for the discussion on the nature of the asymmetry between subject and object relative clauses. We analyze data from a spontaneous production corpus of a young European Portuguese speaking child that confirm that object relatives often have inanimate antecedents. We also conducted an elicited production task, inspired on Novogrodsky and Friedmann 2006, which elicited relative clauses manipulating the animacy of the antecedent. 42 European Portuguese children aged 4 to 6 participated in this task, as well as a control group of 20 adults. Results from the elicited production task show a higher production of object relatives with inanimate antecedents in both groups, although the difference was only significant for the adults. We conclude that the animacy of the antecedent is a feature that may play a role in the production of relatives.

KEY WORDS: language acquisition; relative clauses; animacy 


\section{Introduction}

Asymmetries between subject and object relative clauses in language acquisition are well documented in the literature for numerous languages (Belletti and Contemori 2010, for Italian; Friedmann and Novogrodsky 2004, for Hebrew; de Villiers et al. 1979, for English; Corrêa 1995, for Brazilian Portuguese; among others). The difficulties observed with object relatives are sensitive to the feature similarity between the antecedent and the subject that intervenes between the displaced constituent and its trace (Friedmann, Belletti and Rizzi 2009; Durrleman, Bentea and Guasti 2016). In this paper, we explore the possibility that the animacy features of the antecedent may play a role in the production of relative clauses. In particular, based on previous findings (Kidd et al. 2007) we expected that the production of object relatives would increase with inanimate antecedents.

The paper is organized as follows: in section 2., we introduce the relevant theoretical background; in section 3., we provide some data from spontaneous production; in section 4., we present the elicited production task that we applied; and in section 5., we discuss the results and present our main conclusions.

\section{Background}

Asymmetries between subject and object relative clauses have been found both in production and comprehension crosslinguistically (Belletti and Contemori 2010; Corrêa 1995; Friedmann and Novogrodsky 2004; Tavakolian 1981; de Villiers et al. 1979; Vasconcelos 1991; among others), and have shown that several factors play a role, including the embeddedness of the relative clause (center-embedded, modifying the subject, vs. right-branching, modifying the object) and the syntactic function of the head noun.

As for European Portuguese, in a previous study that elicited the production of right-branching subject and object relatives in a group of 60 children, aged 3;9 to 6;2, and a control group of 20 adults, Costa, Lobo and Silva (2011) have shown that there is a high discrepancy between the rates of production of subject relative clauses vs. object relative clauses both in children and adults. Subject relatives are produced more frequently than object relatives both by children ( $78 \%$ vs. $31 \%)$ and adults $(99,5 \%$ vs. $49,5 \%)$. However, the two groups differed qualitatively: when adults 
do not produce an object relative, they produce a grammatical sentence: a subject relative with passive (e.g. ...que é abraçado pelo avô "that is hugged by the grandfather") or a reduced passive (e.g. abraçado pelo avô "hugged by the grandfather"). Both are adequate in the context. Children, in contrast, often produce inadequate or ungrammatical sentences: they change the order of the arguments (thematic role reversal) (e.g. que abraça o $a v \hat{o}$ "that hugs the grandfather"); they use resumptive forms, filling the gap either with a pronoun or repeating the head noun, which is ungrammatical in European Portuguese (e.g. que o avô o abraça "that the grandfather hugs him" or ...que o avô abraça o menino "that the grandfather hugs the boy"). The same participants also completed a comprehension task, which was a picture selection task. The structures used in the comprehension task all had reversible situations, both the subject and the object were animate, and only right-branching relatives were included (e.g. Mostra-me a menina que a avó abraça "Show me the girl that the grandmother hugs"). Adults performed very well both in subject and object relatives (100\% in both cases), unlike children, who had trouble with object relative clauses (subject relatives: $96 \%$ vs. object relatives: $68 \%$ ).

Subject-object asymmetries are not exclusive of relative clauses. They have been found in other structures that involve A-bar movement, such as wh-questions, topicalization and clefts, for many languages (Friedmann, Belletti, Rizzi 2009, Cerejeira 2009, Adani et al. 2010, Abalada 2011, Costa, Grillo, Lobo 2012, Lobo, Santos and Soares-Jesel 2016, among others).

These asymmetries have been attributed to a specific processing difficulty with structures that involve intervention, as proposed by Friedmann, Belletti and Rizzi (2009): children have trouble establishing a chain between the head $\mathrm{X}$ and the tail $\mathrm{Z}$ of a chain established by movement when an element $\mathrm{Y}$ with similar features intervenes, that is when $\mathrm{X}$ c-commands $\mathrm{Y}$ and $\mathrm{Y}$ c-commands $\mathrm{Z}$ :

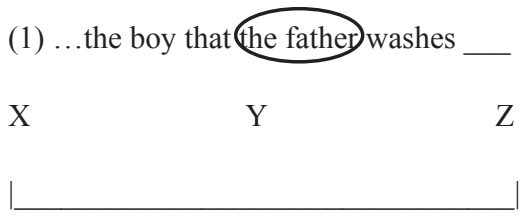

The intervention effects have been shown to be sensitive to the features shared by the moved element and the intervener. Not all features seem to be relevant, though. Features that have an effect are lexical 
features (Friedmann, Belletti and Rizzi 2009, Costa, Grillo and Lobo 2012) and number and gender features (Adani 2008, 2011; Belletti et al. 2012). Therefore, headed relatives with a DP intervener and lexically restricted wh questions with a DP intervener $\left(D_{i} \ldots D P \ldots t_{i}\right)$ are more difficult than free relatives, bare wh-questions $\left(\mathrm{Op}_{\mathrm{i}} \ldots \mathrm{DP} \ldots \mathrm{t}_{\mathrm{i}}\right)$ and are more difficult than wh-structures with an empty subject $\left(\mathrm{DP}_{\mathrm{i}} \ldots\right.$ pro $\ldots$ $\left.\mathrm{t}_{\mathrm{i}}\right)$. Structures where the moved element and the intervener share the same features, as in i), are more difficult than structures where there is only partial overlap of features, as in ii):

i) $\mathrm{DP}_{\mathrm{A}} \ldots \mathrm{DP}_{\mathrm{A}} \ldots \mathrm{t}$

ii) $\mathrm{DP}_{\mathrm{A}} \ldots \mathrm{DP}_{\mathrm{B}} \ldots \mathrm{t}$

Categorical features in contrast do not seem to matter for intervention: PP relatives and PP wh-questions are not easier than object DP relatives and wh-questions (Costa, Friedmann, Silva and Yachini 2014, 2015; Baião and Lobo 2014).

Previous studies have also mentioned the animacy features of the arguments as relevant in the processing of dependencies (cf. Goodluck 2010; Garraffa and Grillo 2008). Corrêa (1995) shows that the number of [+ animate] DPs in the sentence affects children's performance. In younger age groups (3 and 4 year olds) children's performance was affected by animacy. In an act-out task, children had a better performance in a sentence like (2), where the antecedent was inanimate and the subject intervener was animate, than in a sentence like (3), in which both arguments were animate:

(2) O carneiro empurra a cerca que o cavalo derrubou.

The lamb pushes the fence that the horse kicked

(3) O porco empurra o carneiro que o cavalo derrubou.

The pig pushes the lamb that the horse kicked

Durrleman, Bentea and Guasti (2016), in a study with Frenchspeaking children, found an asymmetry in the comprehension of relative clauses with [ + animate] and [- animate] antecedents. Relative clauses were comprehended better when there was an animacy mismatch, especially in the younger groups ( 5 and 7 year olds). The authors conclude that animacy features, that are not morphologically realized, are also relevant for the calculation of relativezed minimality. 
The role of antecedent animacy has mainly been explored in comprehension studies. There are, however, studies that look at antecedent animacy in production. Kidd et al. (2007) show that object relatives in the spontaneous production of German and English children are mostly found with: a) inanimate antecedents; and b) subject pronouns. In a sentence repetition task, they found better performance of object relatives with an inanimate antecedent and of object relatives with a pronominal subject: subject-object asymmetries disappeared with inanimate antecedents.

In the present study, taking into account the role described by the animacy features of the antecedent in relative clauses, we investigate the role of animacy features of the antecedent in the production of object relative clauses, by considering data from spontaneous production (3.) and from an elicited production task (4.). We expected that: i) the production of object relatives would be higher with inanimate antecedents in spontaneous production; ii) the rate of production of object relatives with an animacy mismatch between the head noun (inanimate) and the subject intervener (animate) would be higher in elicited production tasks.

\section{Spontaneous production}

Since Kidd et al. (2007) report that object relative clauses in spontaneous production data predominantly have an inanimate antecedent or a subject pronoun (see also Diessel and Tomasello 2000), we searched Santos's corpus. This corpus includes longitudinal data from three children aged between $1 ; 5$ and $3 ; 11$ (INI - 1;6.6-3;11.12; TOM - 1;6.18$3 ; 10.16$; INM - 1;5.9 - 2;9.3) and is described in detail in Santos (2006) and Santos et al. (2014). In the present study we only considered data from TOM, since this child has been recorded more often and for a longer period.

In TOM's files from $(1 ; 6$ to $3 ; 10)$, which correspond to 30 sessions, we found 77 relative clauses produced by the child. These include 32 object relatives and 45 subject relatives, as shown in Table 1: 


\begin{tabular}{|c|c|c|c|c|c|}
\hline \multirow[t]{2}{*}{ Sessions } & \multicolumn{2}{|c|}{ Subject Relatives } & \multicolumn{2}{|c|}{ Object Relatives } & \multirow[t]{2}{*}{ Total } \\
\hline & $\begin{array}{l}\text { - animate } \\
\text { antecedent }\end{array}$ & $\begin{array}{l}+ \text { animate } \\
\text { antecedent }\end{array}$ & $\begin{array}{l}\text { - animate } \\
\text { antecedent }\end{array}$ & $\begin{array}{l}+ \text { animate } \\
\text { antecedent }\end{array}$ & \\
\hline $1 ; 6-2 ; 1.7$ & 0 & 0 & 0 & 0 & 0 \\
\hline $2 ; 2.9$ & 0 & 0 & 1 & 0 & 1 \\
\hline $2 ; 3.9$ & 0 & 1 & 0 & 0 & 1 \\
\hline $2 ; 4.0$ & 0 & 0 & 0 & 0 & 0 \\
\hline $2 ; 5.3$ & 3 & 0 & 0 & 0 & 3 \\
\hline $2 ; 6.6$ & 1 & 0 & 0 & 0 & 1 \\
\hline $2 ; 7.13$ & 1 & 0 & 0 & 0 & 1 \\
\hline $2 ; 8.9$ & 0 & 1 & 1 & 0 & 2 \\
\hline $2 ; 9.7$ & 0 & 0 & 3 & 0 & 3 \\
\hline $2 ; 9.22$ & 1 & 0 & 1 & 0 & 2 \\
\hline $2 ; 11.0$ & 2 & 4 & 0 & 0 & 6 \\
\hline $2 ; 11.12$ & 1 & 0 & 0 & 0 & 1 \\
\hline $2 ; 11.26$ & 0 & 0 & 1 & 0 & 1 \\
\hline $3 ; 0.22$ & 1 & 1 & 1 & 0 & 3 \\
\hline $3 ; 1.25$ & 1 & 3 & 0 & 0 & 4 \\
\hline $3 ; 2.29$ & 1 & 1 & 1 & 0 & 3 \\
\hline $3 ; 3.25$ & 1 & 0 & 1 & 3 & 5 \\
\hline $3 ; 4.25$ & 1 & 1 & 1 & 0 & 3 \\
\hline $3 ; 6.0$ & 1 & 1 & 3 & 0 & 5 \\
\hline $3 ; 6.17$ & 5 & 1 & 0 & 0 & 6 \\
\hline $3 ; 7.29$ & 5 & 0 & 11 & 0 & 16 \\
\hline $3 ; 8.15$ & 1 & 4 & 4 & 0 & 9 \\
\hline \multirow[t]{2}{*}{$3 ; 10.16$} & 0 & 1 & 0 & 0 & 1 \\
\hline & $\begin{array}{l}26 / 45 \\
(57.8 \%)\end{array}$ & $\begin{array}{l}19 / 45 \\
(42.2 \%)\end{array}$ & $\begin{array}{l}29 / 32 \\
(90.6 \%)\end{array}$ & $\begin{array}{l}3 / 32 \\
(9.4 \%)\end{array}$ & \\
\hline Total & $\begin{array}{l}45 / 77 \\
(58.4 \%)\end{array}$ & & $\begin{array}{l}32 / 77 \\
(41.6 \%)\end{array}$ & & $\begin{array}{l}77 \\
(100 \%)\end{array}$ \\
\hline
\end{tabular}

Table 1. Frequency of subject and object relatives in TOM's files 
Most object relatives produced by the child have an inanimate antecedent (29 out of 32, which corresponds roughly to $90 \%$ ). In (4) to (9) we give some examples of sentences with an object relative clause produced by the child:

(4) Uma coisa assim que tu não sabes (TOM 3;0.22)

a thing so that you not know

"A kind of thing that you don't know"

(5) Aqueles passarinhos que eu vi estavam numa gaiola grande (TOM 3;3.25)

those little.birds that I saw were in.a cage big

"Those little birds that I saw were in a big cage"

(6) Tem aqui um jogo que ainda não fiz (TOM 3;6.0)

has here a game that yet not did

"There is a game here that I haven't done yet"

(7) Olha o avião que o meu pai fez (TOM 3;7.29)

look the plane that the my dad did

"Look at the plane that my dad has done"

(8) Isto são duas bolotas que eu apanhei na minha escola (TOM $3 ; 7.29)$

this are two acorns that I grabbed in.the my school

"These are two acorns that I picked at school"

(9) Mas já não digo a coisa que eu ia dizer (TOM 3;8.15)

but already not say the thing that I was.going (to) say

"But I am not saying the thing that I was going to say anymore"

The animacy of the antecedent is more balanced in subject relatives (57,8\% inanimate antecedents vs. $42,2 \%$ animate antecedents). Some examples are given below. They include transitive verbs, intransitive verbs and copular verbs:

(10) A história que tem muitas canções do pai (TOM 3;0.22) the story that has many songs from daddy

(11) Só falta o gatinho que tem o prato (TOM 3;0.22) just is.missing the kitten that has the dish "There's just the kitten with the dish that is missing"

(12) Ele mordeu aqui o crocodilo que ficou todo arranhado (TOM $3 ; 1.25$ )

he bit here the crocodile that became all scratched

(13) O ninho que estava lá em baixo na relva (TOM 3;3.25)

the nest that was there in down in.the grass

"The nest that was down there on the grass" 
(14) E outro animal que está a pôr a pata de fora (TOM 3;6.0) and other animal that is to put the paw outside "And another animal that is putting his paw outside"

(15) Eu estou a escolher quais são as cartas que calharam-me nos chupas (TOM 3;6.17)

I am choosing which are the cards that got me in the lollypops "I am choosing the cards that I got in the lollypops"

(16) Anda cá ler esta que é muito difícil de ler e eu não sei (TOM $3 ; 7.29)$

come here read this.one that is very difficult to read and I don't know

"Come here and read this one that is very difficult to read and I can't'"

(17) Tenho um peão que dorme no chão (TOM 3;8.15)

I have a pawn that sleeps on.the floor

"I have a pawn that sleeps on the floor"

As described by Kidd et al. (2007) for the acquisition of English and German, in this Portuguese child, object relative clauses also often have a subject pronoun (27 out of 32) - mostly first person pronouns, but also second person pronouns (null or overt), as shown in Table 2:

\begin{tabular}{|lllll|}
\hline DP & $\mathbf{1}^{\text {st }} \mathbf{s g}$. pron. & $\mathbf{2}^{\text {nd }} \mathbf{s g}$. pron. & $\mathbf{1}^{\text {st }}$ pl. pron. & Total \\
5 & 22 & 4 & 1 & 32 \\
\hline
\end{tabular}

Table 2. Types of subjects in object relatives in TOM's files

The spontaneous production data from this child partly confirms thus what has been described for other languages: i) object relatives mostly have inanimate antecedents; ii) object relatives often have a subject pronoun. The proportion of subject and object relatives, however, is not the same as the one described in Kidd et al. (2007). Subject relatives are more frequent than object relatives in this child's production data.

Therefore, the animacy features of the antecedent seem to be a factor that influences the production of object relatives, but other factors have to be taken into account. 


\section{Elicited Production}

\subsection{Goals}

Taking into account previous results that describe an effect of the animacy of the antecedent both in the production and in the comprehension of relative clauses, we decided to investigate the effect of the animacy of the antecedent in the production of object relative clauses through an elicited production task, inspired on Novogrodsky and Friedmann (2006) and following Costa, Lobo and Silva (2011). Specifically, we wanted to find out whether inanimate antecedents would lead to higher rates of production of object relatives.

We also wanted to compare children and adult strategies, in order to find out whether relative clauses with inanimate antecedents would differ from relative clauses with animate antecedents in the use of thematic role reversals in children's data. Previous studies have found that one of the main error found in children's productions is the reversal of the subject and object: the child produces a subject relative instead of an object relative that would be required by the context (e.g. I would rather be the child that hugs the grandfather instead of I would rather be the child that the grandfather hugs). This can be seen as the result of the difficulty in computing sentences where there is feature intervention between the head noun and the gap position. With inanimate antecedents, we expected children to have less role reversals, since there would be only partial feature sharing.

\subsection{Methodology}

We tested 42 children (4 to 6 year-olds) living in the Lisbon area and a control group of 20 adults. Details are given in Table 3.

\begin{tabular}{|l|c|c|c|}
\hline Group & N & Age range & Mean Age \\
\hline 4 year-olds & 17 & $4 ; 0-4 ; 9$ & $4 ; 5$ \\
\hline 5 year-olds & 19 & $5 ; 0-5 ; 10$ & $5 ; 5$ \\
\hline 6 year-olds & 6 & $6 ; 1-6 ; 7$ & $6 ; 4$ \\
\hline children & $\mathbf{4 2}$ & $\mathbf{4 ; 0}-\mathbf{6 ; 7}$ & $5 ; 2$ \\
\hline adults & $\mathbf{2 0}$ & $\mathbf{1 8}-\mathbf{5 4}$ & 29 \\
\hline
\end{tabular}

Table 3. Participants 
We used an elicited production task that induced the production of relative clauses and we manipulated both the syntactic function of the relative (subject relative / object relative) and the animacy of the antecedent (animate / inanimate). The task had a total of 40 items, 10 in each condition:
a) Object Relative with animate antecedent (AOR)
10 items
b) Subject Relative with animate antecedent (ASR)
10 items
c) Object Relative with inanimate antecedent (NAOR)
10 items
d) Subject Relative with inanimate antecedent (NASR)
10 items

The child was told he/she had to choose what child he preferred to be or what object he/she preferred to have. The experimenter told the child two situations and the child had to say which situation he preferred. No pictures were presented and no relative clause was included in the stimuli. The restriction of the relevant subject/object could induce the production of a relative clause (although it did not force its production).

We present an example of a test item for each condition:

(18) Subject Relative Animate Antecedent (ASR)

Há dois meninos. Um menino abraçou a mãe. Outro menino abraçou a avó.

Que menino é que preferias ser?

There are two boys. One boy hugges his mother. The other boy hugged his grandmother.

Which boy would you rather be?

Expected answer: Preferia ser o menino que abraçou a mãela avó. I would rather be the boy that hugged his mother/grandmother.

(19) Subject Relative Inanimate Antecedent (NASR)

O pai fez dois desenhos. Um desenho tem um dinossauro. Outro desenho tem um super-herói.

Que desenho é que preferias ter?

Daddy made two drawings. One drawing has a dinosaur. The other drawing has a super-hero. Which drawing would you rather have?

Expected answer: Preferia ter o desenho que tem um dinossauro/um super-herói.

I would rather have the picture that has a dinosaur /a super-hero. 
(20) Object Relative Animate Antecedent (AOR)

Há dois meninos. O pai abraçou um menino. O tio abraçou outro menino.

Que menino é que preferias ser?

There are two boys. The father hugged one boy. The uncle hugged the other boy.

Which boy would you rather be?

Expected answer: Preferia ser o menino que o pai/o tio abraçou.

I would rather be the boy that the father/the uncle hugged.

(21) Object Relative Inanimate Antecedent (NAOR)

Há duas bicicletas. O pai lavou uma bicicleta. O pai arranjou outra bicicleta.

Que bicicleta é que preferias ter?

There are two bicycles. The father washed one bicycle. The father mended the other bicycle.

Which bicycle would you rather have?

Expected answer: Preferia ter a bicicleta que o pai lavou/arranjou.

I would rather have the bicycle that the father washed/mended.

Notice that the task allows for the production of a relative, but other structures may be used instead.

\subsection{Results}

In figure 1 and table 4 , we present the rate of production of the intended structure in each condition by age group:

\begin{tabular}{|l|l|l|l|l|}
\hline & ASR & AOR & NASR & NAOR \\
\hline $\mathbf{4}$ & $89 / 170$ & $52 / 170$ & $37 / 170$ & $53 / 170$ \\
& $52,4 \%$ & $30,5 \%$ & $21,8 \%$ & $31,2 \%$ \\
\hline $\mathbf{5}$ & $148 / 190$ & $63 / 190$ & $78 / 190$ & $75 / 190$ \\
& $77,9 \%$ & $33,2 \%$ & $41 \%$ & $39,5 \%$ \\
\hline $\mathbf{6}$ & $50 / 60$ & $33 / 60$ & $19 / 60$ & $26 / 60$ \\
& $83,3 \%$ & $55 \%$ & $31,6 \%$ & $43,3 \%$ \\
\hline Children & $287 / 420$ & $\mathbf{1 4 8} / \mathbf{4 2 0}$ & $134 / 420$ & $\mathbf{1 5 4 / 4 2 0}$ \\
& $68,3 \%$ & $\mathbf{3 5 , 2} \%$ & $31,9 \%$ & $\mathbf{3 6 , 7 \%}$ \\
\hline Adults & $191 / 200$ & $\mathbf{9 4 / 2 0 0}$ & $74 / 200$ & $\mathbf{1 1 5 / 2 0 0}$ \\
& $95,5 \%$ & $\mathbf{4 7 \%}$ & $42 \%$ & $\mathbf{5 7 , 5 \%}$ \\
\hline
\end{tabular}

Table 4. Proportion and percentage of intended structure by condition and group 


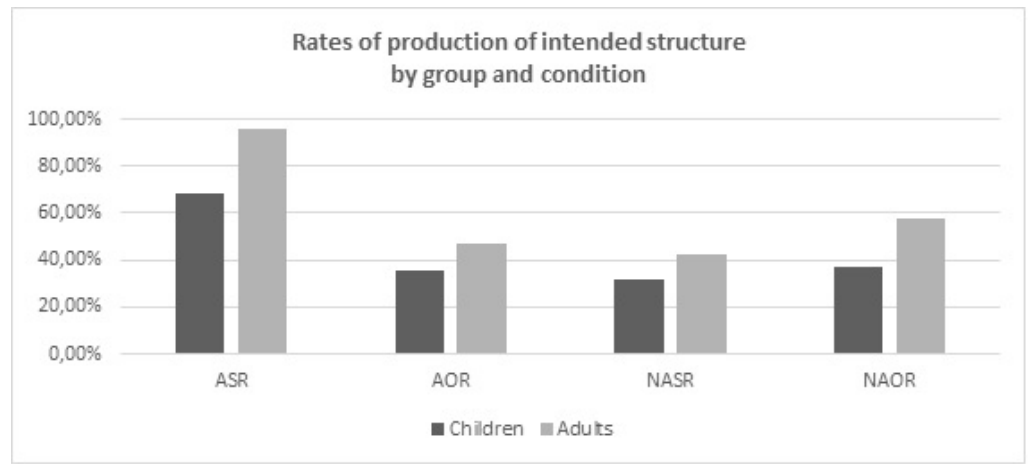

Figure 1. Percentage of production of target structure in each condition by group

As we can observe, in the conditions with animate antecedents (ASR and AOR), subject relatives were produced much more often than object relatives in both groups, in accordance with what was found in previous studies and with similar results. Comparing object relatives with animate and inanimate antecedents, we observe that the production of relatives in the object relative conditions with inanimate antecedents (NAOR) was higher than the one observed with animate antecedents, although the difference is small in children (47\% vs. $57,5 \%$ for adults; $35,2 \%$ vs. $36,7 \%$ for children). The production of subject relatives with inanimate antecedents was much lower than with animate antecedents and it was also lower than the production of object relatives with inanimate antecedents.

In order to determine whether the differences between groups and conditions were significant, we used a Chi-squared Independence Test. The statistical analysis resorted to $\mathrm{R}$ software, version 3.4.0.

Differences between subject relatives and object relatives with animate antecedents were highly significant for both groups. We performed 2 (group: children vs. adults) x 2 (Animate antecedents: subject relatives (ASR) vs. object relatives (AOR) Chi-squared Independence Tests, one by participants and one by items. The main effect of subject relatives and object relatives was significant (children (ASR, AOR): $\chi^{2}(1)=92.12 ; \mathrm{p}$ $<0.05$; adults (ASR, AOR): $\chi^{2}(1)=114.83 ; \mathrm{p}<0.05$ ).

Although there is a higher rate of production of object relatives with inanimate antecedents than object relatives with animate antecedents in both groups, we only found a significant effect of the animacy features of 
the antecedent in the production of object relatives in the adult group. We performed 2 (group: children vs. adults) x 2 (Object relatives: inanimate antecedents (NAOR) vs. animate antecedents (AOR)) Chi-squared Independence Tests, one by participants and one by items. The main effect of animacy in object relatives is not significant among children (children (NAOR, AOR): $\left.\chi^{2}(1)=0.18612 ; \mathrm{p}>0.05\right)$, but significant among adults (adults (NAOR, AOR) ): $\left.\chi^{2}(1)=4.4189 ; \mathrm{p}<0.05\right)$.

As for the difference between subject relatives with animate antecedents and subject relatives with inanimate antecedents, we observe that the production of relatives is higher in the animate condition in both groups, although the fact that the relative clause in the inanimate condition contained a stative verb (ter) may be responsible for this effect. We performed 2 (group: children vs. adults) x 2 (Subject relatives: inanimate antecedents (NASR) vs. animate antecedents (ASR)) Chisquared Independence Tests, one by participants and one by items. The main effect of animacy in subject relatives is significant in both groups (children (NASR, ASR): $\chi 2(1)=111,47 ; \mathrm{p}>0.05)$; adults (NASR, ASR) ): $\chi 2(1)=153,06 ; \mathrm{p}<0.05)$.

As for the difference between subject relatives with inanimate antecedents and object relatives with inanimate antecedents, we see that both groups produce more relatives in the object condition, although the difference is higher in the adult group. We performed 2 (group: children vs. adults) x 2 (Inanimate antecedents: subject relatives (NASR) vs. object relatives (NAOR)) Chi-squared Independence Tests, one by participants and one by items. The main effect of subject relatives and object relatives was significant in the adult group (adults (NASR, NAOR): $\chi 2(1)=$ 16,$861 ; \mathrm{p}<0.05$ ), but not in children (children (NASR, NAOR): $\chi^{2}(1)$ $=2,1135 ; \mathrm{p}>0.05)$

Differences between children and adults were found in all conditions, except for the inanimate subject relatives.

Let us now look at the type of structures that children and adults produced, in order to determine whether there are qualitative differences between them.

As in previous studies (Costa, Lobo \& Silva 2011), we found qualitative differences between children and adults. In the OR conditions, besides object relative clauses, adults produced other structures, most of them adequate in the context and grammatical. These included:

Subject relatives with a passive: 
(22) a. a flor que foi regada the flower that was watered

b. o menino que foi abraçado pelo pai the boy that was hugged by.the father

Reduced passives - participial clause:

(23) a. a camisola tricotada pela avó the pullover knitted by.the grandmother

b. o menino penteado pelo pai the boy combed by.the dad

Adjectival or prepositional modifiers:

(24) a. o menino da mãe / o do avô the boy of.the mother / the(one) of.the grandfather

b. as calças novas the pants new

Children also produced these structures but to a lesser extent, and they produced structures that were absent from the adult group, which are ungrammatical or inadequate, such as i) subject relatives with a change of head or thematic role reversal (17); ii) object relatives with a resumptive DP (18); iii) relatives with a null argument (19); iv) non-finite clauses (20); v) non-dependent finite clauses (21):

(25) a. o menino que desenha a mãe the boy that draws the mother

b. o avô que pintou o castelo the grandfather that paints the castle

(26) a. o quadro que o avô pintou o quadro the picture that the grandfather painted the picture

b. o que o pai fotografou o menino the (one) that the father photographed the boy

(27) o que pintou the(one) that painted

(28) a. o avô a fotografar o menino the grandfather photographing the boy

b. o castelo de construir the caste of building (29) a. o avô pintou o quadro the grandfather painted the picture

b. a tia desenha um menino the aunt draws a boy 
The proportion of structures produced in the object relative conditions is illustrated in Table 5:

\begin{tabular}{|l|l|l|l|l|}
\hline & \multicolumn{2}{|l|}{ Children } & \multicolumn{2}{l|}{ Adults } \\
\hline & AOR & NAOR & AOR & NAOR \\
\hline Object Relative & $35,2 \%$ & $36,7 \%$ & $47 \%$ & $57,5 \%$ \\
\hline Subject Relative with Passive & $3,3 \%$ & $2,4 \%$ & $13 \%$ & $14 \%$ \\
\hline Reduced Passive & $1,7 \%$ & $12,1 \%$ & $35 \%$ & $26 \%$ \\
\hline $\begin{array}{l}\text { Prepositional / Adjectival } \\
\text { Phrase }\end{array}$ & $7,9 \%$ & $2,6 \%$ & $4,5 \%$ & $2 \%$ \\
\hline Non-finite clauses & $2,9 \%$ & 0 & 0 & 0 \\
\hline $\begin{array}{l}\text { Subject Relative (change of } \\
\text { head or change of thematic role) }\end{array}$ & $6,7 \%$ & $2,1 \%$ & $0,5 \%$ & $0,5 \%$ \\
\hline $\begin{array}{l}\text { Object Relative with resumptive } \\
\text { pronoun or noun phrase }\end{array}$ & $14,8 \%$ & $3,3 \%$ & 0 & 0 \\
\hline Other & $27,6 \%$ & $40,7 \%$ & 0 & 0 \\
\hline
\end{tabular}

Table 5. Structures produced in the object conditions

As we can see in figures 2 and 3, children produce many inadequate or ungrammatical structures, whereas adults use different grammatical strategies. The rate of structures that avoid the intervention configuration (change of head or change of thematic role and resumptive strategies) are higher in the AOR condition.

As for subject relatives, in the animate condition, adults produced almost exclusively relatives, whereas in the inanimate condition, they used many PP or AP modifiers. These structures are also possible in the given context. The fact that the sentences in the NASR condition included the non-eventive verb ter with an inanimate complement may have contributed to a higher production of non-sentential modifiers in this condition. Children produced the same kind of structures, but with a higher rate of non-sentential modifiers (PP and AP). 


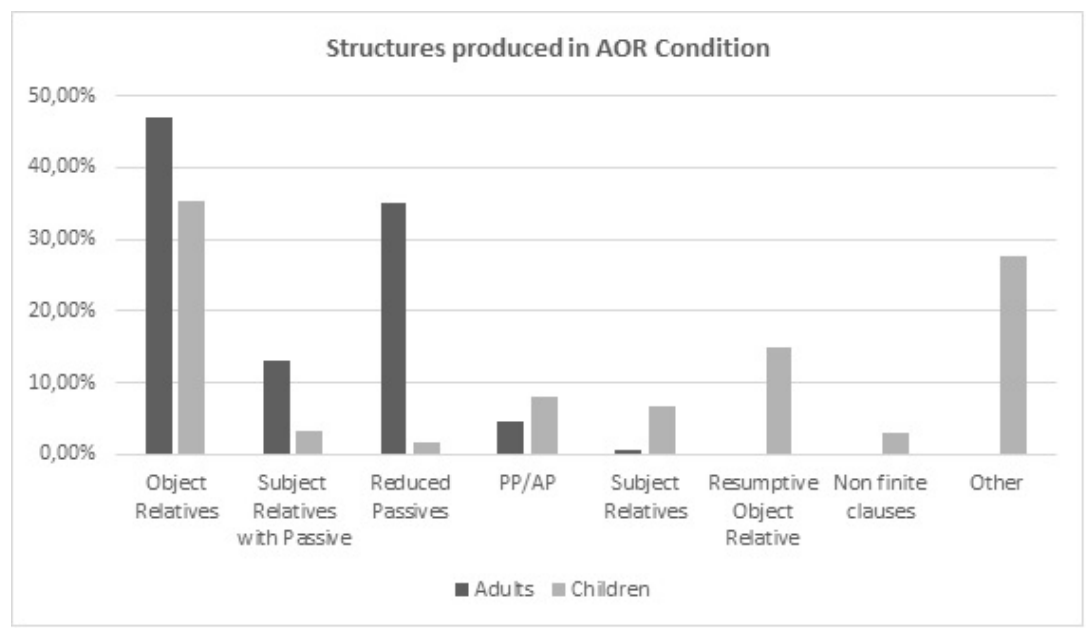

Figure 2. Structures produced in the AOR Condition

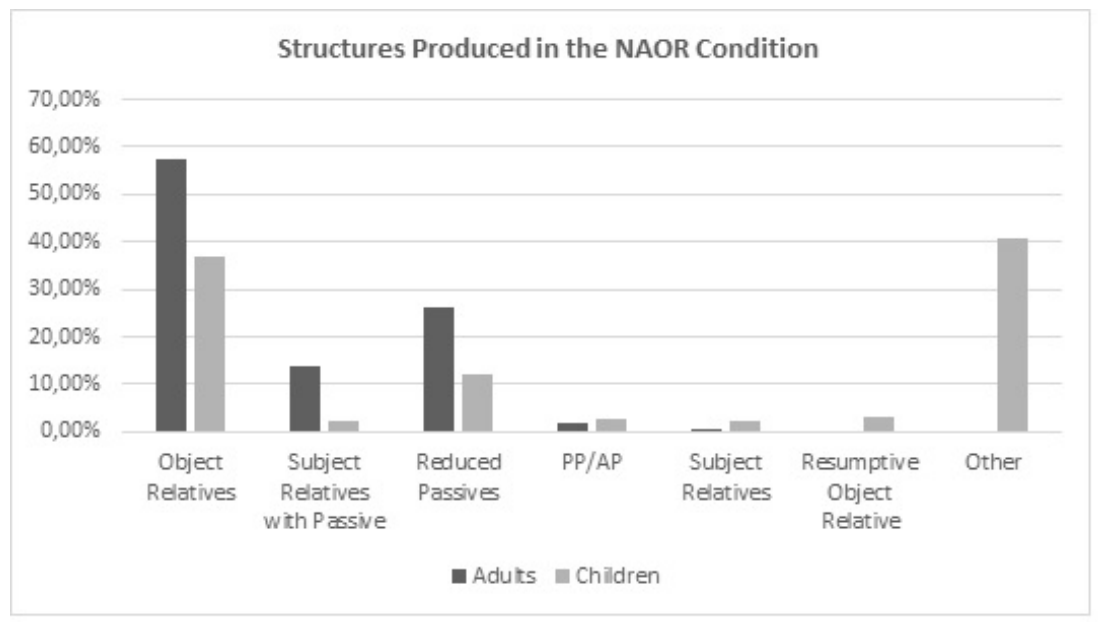

Figure 3. Structures produced in the NAOR Condition

\section{Discussion and Conclusions}

As we have mentioned in section 2, previous studies have reported that the animacy of the antecedent plays a role in the production and comprehension of relative clauses in particular for children. Relative clauses 
with inanimate antecedents are more frequent in spontaneous production data, and easier to produce in sentence repetition tasks (Kidd et al., 2007). Animacy mismatch between antecedent and intervener facilitates the comprehension of object relatives (Durrleman, Bentea and Guasti, 2016).

Kidd et al. (2007) attribute these effects to distributional and discourse regularities of the input and claim that the same constraints apply in children and adults' processing of relative clauses. Durrleman, Bentea and Guasti (2016) discuss which types of features impact the comprehension of relatives, and propose that not only morphologically expressed features, such as gender and number, are relevant. The authors found an effect of animacy features, which are morphologically unexpressed in French: object relatives with an animacy mismatch (inanimate antecedent and animate subject intervener) were easier to comprehend than object relatives where both the antecedent and the subject intervener were animate.

If there is a mismatch between the animacy features of the subject and the object and if feature dissimilarity facilitates the computation, structures with inanimate object antecedents and animate subjects may be easier also to produce.

Our study has confirmed previous results for other languages in what concerns spontaneous production data: i) object relatives with inanimate antecedents are much more frequent than object relatives with animate antecedents; and ii) subjects of object relatives are often pronouns, in particular first and second person pronouns. A subject pronoun does not have lexical features and thus does not give rise to intervention effects in the same way as a full DP does. Moreover, if the pronoun is a first or second person pronoun (see Table 2), there will also be a mismatch in person features. Therefore, these structures are presumably easier to produce, supporting the idea that different types of features (referentiality, person, number and crucially also animacy) impact the production of relative clauses: structures where there is a feature mismatch between the antecedent and the subject intervener are more frequent, and possibly easier for the computational system.

As for the elicited production task, our results only partially supported the hypothesis that inanimate antecedents would increase the production of object relatives. Although there was a higher rate of production of object relatives with inanimate antecedents in both children and adults, the effect of the animacy features of the antecedent in the production of object 
relatives was only significant in the adult group. Differently from Kidd et al. (2007), who used a sentence repetition task, our study used an elicited production task, which did not force the participants to produce an object relative. They could resort to alternative structures and in fact they did.

Therefore, the freedom of responses that can be obtained in an elicited production task and the fact that the participant may simply avoid the production of a complex sentence, choosing instead to produce a reduced clause, a non-clausal modifier, or other less complex strategy, may have been responsible for the absence of an animacy effect in object relatives in children's data. The qualitative analysis of children's responses showed us that role reversals are more frequent in AOR, although they occasionally occur in NAOR. However, the fact that both in AOR and in NAOR children produce structures that involve thematic role reversal (changing an OR into a SR) and structures that involve gap filling (resumptive strategies) shows that NAOR are also difficult structures for children. Therefore, the animacy mismatch in OR does not eliminate the intervention effect, although it seems to alleviate it. This seems to support the data found for comprehension in the study by Durrleman et al. (2016): an animacy mismatch facilitates the computation of object relatives and causes a weaker intervention, although the intervention does not disappear.

We also found an asymmetry between subject and object relatives with inanimate antecedents, object relatives being produced more often in the NAOR than in the NASR, which was not initially expected. In this case, the discrepancy cannot be attributed to intervention, since there is no intervener between the head noun and the gap in subject relatives. Notice that the subject relatives that we included had the stative verb ter with an inanimate complement. This allowed more easily for an adjectival or prepositional phrasal modifier and this was precisely what most children and adults did. Therefore, the interpretation of production data has to be taken with caution. There may be independent reasons that trigger the production of different strategies both in children and adults and not everything may be explained by computational costs and intervention effects. Methodological issues, namely the type of verb used in the experimental test in the inanimate subject conditions, may in part explain the results we obtained.

We cannot exclude the fact that object relatives with inanimate antecedents may be more frequent for semantic and discourse reasons. Whereas there is a strong bias for subjects to be animate, such restriction does not apply to objects, which tend to be inanimate, as is generally 
reflected in thematic hierarchies, such as the ones proposed in Jackendoff (1972) or Belleti and Rizzi (1988), for instance. Whenever a verb has two arguments, the subject argument will generally be associated to a thematic role that is usually constrained with animacy features.

To complement the data from production, it would be necessary to test the comprehension of object relatives with animate and inanimate antecedents, such as in (30) and (31), to see if the effect shows up in this case:

(30) Show me the ball that the doctor is hiding.

(31) Show me the boy that the doctor is hiding.

There is some evidence that the animacy of the antecedent and the mismatch in animacy features of subject and object does not by itself withdraw the intervention effect, since the DPs will still share lexical features and number features, as shown in Durrleman et al. (2016). We would thus expect a weaker difference between AOR and NAOR than the one we find between ASR and AOR.

Although our study is not completely conclusive, we have shown that: i) object relatives found in children's spontaneous production are generally structures that do not have a complete feature overlap between the head noun and the subject intervener; ii) animacy mismatch in object relatives with inanimate antecedents slightly increases the rate of production, but intervention effects do not disappear.

\section{A ANIMACIDADE DO ANTECEDENTE DESEMPENHA UM PAPEL NA PRODUÇÃO DE ORAÇÕES RELATIVAS?}

\section{RESUMO}

Em estudos anteriores que incluíram tarefas de compreensão e de produção induzida (Costa, Lobo and Silva 2011), mostrou-se que há uma assimetria considerável entre as taxas de produção de orações relativas de sujeito e de objeto, quer nas crianças, quer nos adultos, mas os dois grupos apresentaram diferenças qualitativas. Na tarefa de compreensão, os adultos tiveram um desempenho muito bom, ao contrário das crianças, que tiveram dificuldade com orações relativas de objeto. Estes resultados suportam a hipótese de que há uma dificuldade específica com estruturas que envolvem intervenção (Fried- 
mann, Belletti and Rizzi 2009). No presente trabalho, investigamos o papel de traços de animacidade do antecedente na produção de relativas de objeto, mais especificamente, investigamos se a produção de orações relativas de objeto aumenta com antecedentes não animados. Trabalhos anteriores mencionaram a relevância dos traços de animacidade dos argumentos (Corrêa 1994; Goodluck 2005; Kidd et al. 2007; Durrleman, Bentea and Guasti 2016). Exploramos a relevância destes resultados para a discussão sobre a natureza da assimetria entre orações relativas de sujeito e de objeto. Analisamos dados de produção espontânea de uma criança falante de português europeu que confirmam que a maioria das orações relativas de objeto produzidas pela criança têm antecedentes não animados. Aplicamos ainda uma tarefa de produção induzida, inspirada em Novogrodsky and Friedmann 2006, que induzia a produção de orações relativas manipulando a animacidade do antecedente. Participaram na tarefa 42 crianças falantes de português europeu com idades entre os 4 e os 6 anos e um grupo de controlo de 20 adultos. Os resultados mostram que existe uma produção de relativas de objeto mais elevada com antecedentes não animados, ainda que a diferença tenha sido significativa apenas no grupo dos adultos. Concluímos que a animacidade do antecedente é um fator que desempenha um papel na produção de relativas.

PALAVRAS-CHAVE: aquisição da linguagem; orações relativas; animacidade

\section{REFERENCES}

Abalada, Silvana. (2011) Aquisição de Estruturas com Constituintes na Periferia Esquerda e Direita da Frase em Português Europeu. Diss. Mestrado. FLUL.

Adani, Flavia, Heather K. J. van der Lely, Matteo Forgiarini and Maria Teresa Guasti (2010) Grammatical feature dissimilarities make relative clauses easier: A comprehension study with Italian children. Lingua 120. 2148-2166.

Baião, Vera and Maria Lobo (2014) Aquisição de interrogativas preposicionadas no português europeu, In Textos Selecionados XXIX Encontro Nacional da APL, Coimbra: APL; 57-70.

Belletti, Adriana and Carla Contemori (2010) Intervention and attraction. On the production of Subject and Object relatives by Italian (young) children and adults, In João Costa et al. (eds). Language Acquisition and Development, 3, Cambridge, UK: CSP. 
Belletti, Adriana, Naama Friedmann, D. Brunato and Luigi Rizzi (2012) Does gender make a difference? Comparing the effect of gender on children's comprehension of relative clauses in Hebrew and Italian. Lingua 122. 1053-1069.

Belletti, Adriana and Luigi Rizzi (1988) Psych-verbs and q-Theory. Natural Language and Linguistic Theory 6.3; 291-352.

Cerejeira, Joana (2009) Aquisição de interrogativas de sujeito e de objecto em português europeu. Diss. Mestrado. FCSH-UNL.

Corrêa, Letícia Sicuro (1995) An alternative assessment of children's comprehension of relative clauses. Journal of Psycholinguistic Research 24.3; 183-203.

Costa, João, Maria Lobo and Carolina Silva (2011) Subject-object asymmetries in the acquisition of Portuguese relative clauses: adults vs. children. Lingua 121.6; 1083-1100.

Costa, João, Naama Friedmann, Carolina Silva and Maya Yachini (2015) The acquisition of PP relatives in Hebrew and European Portuguese: Another window into the atoms of intervention. In C. Hamann and E. Ruigendijk (eds.) Language Acquisition and Development: Generative approaches to language acquisition 2013. Newcastle, UK: Cambridge Scholars Publishing.

Costa, João, Naama Friedmann, Carolina Silva and Maya Yachini (2014) The boy that the chef cooked: Acquisition of PP relatives in European Portuguese and Hebrew. Lingua, 150, 386-409.

Costa, João, Nino Grillo and Maria Lobo (2012) Minimality beyond lexical restrictions: Processing and Acquisition of free relatives in European Portuguese, Revue Roumaine de Linguistique/Roumanian Review of Linguistics LVII.2; 143-160.

De Villiers, Jill G, Helen B. Tager Flusberg, Kenji Hakuta and Michael Cohen (1979) Children's comprehension of relative clauses. Journal of Psycholinguistic Research 8(5); 499-518.

Diessel, Holger and Michael Tomasello (2005) A new look at the acquisition of relative clauses. Language $81 ; 1-25$.

Diessel, Holger and Michael Tomasello. 2000. The development of relative clauses in spontaneous child speech. Cognitive Linguistics 11; 131-151.

Durrleman, Stephanie, Anamaria Bentea and Maria Teresa Guasti (2016) Out of Sight, Not Out of Mind: Unexpressed Features Impact Children's Comprehension of Relative Clauses. In J. Scott and D. Waughtal (eds.) Proceedings of the $\mathbf{4 0}^{\text {th }}$ BUCLD. Somerville, MA: Cascadilla Press; 116-129.

Friedmann, Naama and Rama Novogrodsky (2004) The Acquisition of Relative Clause Comprehension in Hebrew: A Study of SLI and Normal Development. Journal of Child Language 31. 661-681. 
Friedmann, Naama, Adriana Belletti and Luigi Rizzi (2009) Relativized relatives: Types of intervention in the acquisition of A-bar dependencies. Lingua 119. 67-88. Garraffa, Maria and Nino Grillo (2008) Canonicity effects as grammatical phenomena. Journal of Neurolinguistics 21; 177-197.

Goodluck, Helen (2010) Object extraction is not subject to Child Relativized Minimality. Lingua 120; 1516-1521.

Jackendoff, Ray (1972) Semantic Interpretation in Generative Grammar. Cambridge, MA: MIT Press.

Kidd, Evan, Silke Brandt, Elena Lieven and Michael Tomasello (2007) Object relatives made easy: A crosslinguistic comparison of the constraints influencing young children's processing of relative clauses. Language and Cognitive Processes 22.6; 860-897.

Lobo, Maria, Ana Lúcia Santos and Carla Soares-Jesel (2016) Syntactic structure and information structure: the acquisition of Portuguese clefts and be-fragments. Language Acquisition 23.2; 142-174.

Novogrodsky, Rama and Naama Friedmann (2006) The production of relative clauses in SLI: a window to the nature of the impairment. Advances in SpeechLanguage Pathology 8; 364-375.

Reinhart, Tanya (1976) The syntactic domain of anaphora. Doctoral dissertation, Massachusetts Institute of Technology. (Available online at http://dspace.mit.edu/ handle/1721.1/16400).

Santos, Ana Lúcia (2006) Minimal Answers. Ellipsis, Syntax and Discourse in the acquisition of European Portuguese. Universidade de Lisboa. (PhD Dissertation) [Published in 2009, John Benjamins].

Santos, Ana Lúcia, Michel Généreux, Aida Cardoso, Celina Agostinho and Silvana Abalada (2014) A corpus of European Portuguese child and child-directed speech. In Proceedings of the 9th Conference on Language Resources and Evaluation - LREC 2014, 1488-1491. European Language Resources Association (ELRA). Tavakolian, Susan (1981) The conjoined clause analysis of relative clauses. In S. Tavakolian, (ed). Language Acquisition and Linguistic Theory. Cambridge MA: The MIT Press, 167-187.

Vasconcelos, Manuela (1991) Compreensão e produção de frases com orações relativas: um estudo experimental com crianças dos três anos e meio aos oito anos e meio. Dissertação de Mestrado, Universidade de Lisboa.

Recebido em: 08/05/2017

Aceito em: 02/08/2017 